\title{
The different pattern of blood S100B protein and GFAP concentrations in ischemic stroke
}

\author{
Yenny Surjawan, ${ }^{1,2}$ Suryani As 'ad, ${ }^{1}$ Teguh A.S. Ranakusuma, ${ }^{3}$ Andi Wijaya ${ }^{1,2}$ \\ ${ }^{1}$ Faculty of Medicine, University of Hasanuddin, Makasar, Indonesia \\ 2 Prodia Clinical Laboratory, Jakarta, Indonesia \\ ${ }^{3}$ Department of Neurology, Faculty of Medicine, Universitas Indonesia, Jakarta, Indonesia
}

\begin{abstract}
Abstrak
Latar belakang: Terdapat kaitan antara stroke dengan protein S100B dan glial fibrillary acidic protein (GFAP) yang terlepas saat iskemia. Kedua protein ini dilepaskan pada keadaan iskemia ke dalam sirkulasi. Penelitian ini bertujuan untuk mengetahui apakah terdapat hubungan antara kadar kedua petanda ini dengan beratnya defisit neurologis pada stroke iskemik.

Metode: Penelitian dilakukan secara potong lintang terhadap 143 pasien stroke iskemik yang datang ke rumah sakit tidak lebih dari 72 jam sejak awitan dan memenuhi kriteria penelitian. Kadar protein S100B dan GFAP diperiksa dengan metode ELISA. Kadar S100B dan GFAP antara penderita stroke ringan, sedang, dan berat dianalisis dengan uji Kruskal Wallis.

Hasil: Didapatkan ada perbedaan bermakna kadar protein S100B antara subyek yang masuk dengan skor NIHSS (National Institute Health Stroke Scale) ringan (nilai median 63,31 $\mathrm{ng} / \mathrm{L}$ ), sedang (nilai median 88,93 $\mathrm{ng} / \mathrm{L}$ ), dan berat (nilai median 511,55 $\mathrm{ng} / \mathrm{L})(p<0,05)$. Ada korelasi lemah namun bermakna antara beratnya NIHSS dengan kadar protein S100B, semakin berat NIHSS semakin tinggi kadar protein S100B $(r=0,351 ; p<0,001)$. Subyek yang masuk dengan NIHSS sedang dan berat lebih sering menunjukkan kadar protein S100B yang sedang dan tinggi daripada subyek yang masuk dengan NIHSS ringan $(O R=3,9 ; p<0,001)$. Nilai median kadar GFAP didapatkan lebih tinggi bermakna pada subyek yang masuk dengan NIHSS berat (nilai median 0,374 $\mathrm{ng} / \mathrm{mL}$ ) daripada yang masuk dengan NIHSS ringan (nilai median 0,047 $\mathrm{ng} / \mathrm{mL}$ ) dan sedang (nilai median 0,043 $\mathrm{ng} / \mathrm{mL})(p<0,05)$.
\end{abstract}

Kesimpulan: Kadar protein S100B semakin tinggi bermakna seiring dengan semakin beratnya NIHSS, sedangkan kadar GFAP yang tinggi bermakna baru didapatkan pada kasus dengan NIHSS yang sudah berat. (Med J Indones. 2013;22:215-20. doi: 10.13181/mji.v22i4.602)

\begin{abstract}
Background: S100B protein and glial fibrillary acidic protein (GFAP) released during ischemia have been associated with stroke. This study aimed to know whether there was a correlation between the concentration of these markers with the severity of neurological deficit in ischemic stroke.
\end{abstract}

\begin{abstract}
Methods: This was a cross-sectional study, which involved 143 ischemic stroke patients who were admitted to hospital not more than 72 hours after the onset and fulfilled the criteria. The concentration of S100B protein and GFAP was determined by ELISA method. Blood level of S100B and GFAP in patient with mild, moderate, and severe stroke were analyzed with Kruskal-Wallis test.
\end{abstract}

Results: There was a significant difference between S100B protein concentration among subjects with mild (median $63.31 \mathrm{ng} / \mathrm{L}$ ), moderate (median $88.93 \mathrm{ng} / \mathrm{L}$ ), and severe (median $511.55 \mathrm{ng} / \mathrm{L}$ ) NIHSS at admission $(\mathrm{p}<0.05)$. A weak significant correlation was found between the severity of NIHSS and the S100B protein concentration. The more severe the NIHSS, the higher the S100B protein concentration $(r=0.351 ; p<0.001)$. Subjects with moderate and severe NIHSS were more frequent to have an intermediate or high level of S100B protein than the subjects with mild NIHSS $(\mathrm{OR}=3.9 ; \mathrm{p}<0.001)$. The median concentration of GFAP was significantly higher in severe NIHSS subjects (median $0.374 \mathrm{ng} / \mathrm{mL}$ ) than its concentration in mild (median $0.047 \mathrm{ng} / \mathrm{mL}$ ) and moderate (median $0.043 \mathrm{ng} / \mathrm{mL}$ ) NIHSS subjects $(\mathrm{p}<0.05)$.

Conclusion: S100B protein concentration was significantly higher in linier relation with the severity of NIHSS, while the GFAP concentration was significantly higher if the NIHSS had been already severe. (Med J Indones. 2013;22:215-20. doi: 10.13181/mji.v22i4.602)

Keywords: GFAP, ischemic stroke, NIHSS, S100B protein

S100B protein and glial fibrillary acidic protein (GFAP) are brain specific markers that had been associated with stroke. S100B protein is located in the cytoplasm of astrocytes and GFAP is expressed in astrocytes cytoskeleton. ${ }^{1,2}$ Although several studies had showed that there was an association between S100B protein and GFAP with stroke, the strength of the association was low and inconsistent. It might be influenced by the subject selection criteria, the severity of stroke, the onset of stroke, and the time of blood collection.

There has not been studied how the stroke severity will influence the concentration of S100B and GFAP in blood. Selection of a suitable marker in further study is required in accordance with the severity of neurological deficit. 
We want to know the concentration of S100B protein and GFAP in mild, moderate, and severe neurological deficit in ischemic stroke.

\section{METHODS}

This was a cross sectional study performed on 143 anterior circulation ischemic stroke patients who were admitted to hospital not more than 72 hours after the onset. Subjects were recruited from several hospitals in Jakarta and Makassar since June 2011 until December 2012. The diagnosis of anterior circulation ischemic stroke was made by neurologist based on the history or anamnesis, physical examination, and CT/MRI. This study has been approved by the Ethics Committee of Medical Faculty of Hasanuddin University, Makassar, Indonesia (Reg. No. UH11030054).

After obtaining informed consent, stroke subjects who had their first attack were included in this study. Patients who had liver dysfunction (female: AST $>54 \mathrm{U} / \mathrm{L}$, ALT $>68 \mathrm{U} / \mathrm{L}$; male: AST > $66 \mathrm{U} / \mathrm{L}$, ALT > $100 \mathrm{U} / \mathrm{L}$ ), serum creatinine $>1.6 \mathrm{mg} / \mathrm{dL}(141.44 \mu \mathrm{mol} / \mathrm{L})$, random blood glucose $<55 \mathrm{mg} / \mathrm{dL}(3.0525 \mathrm{mmol} / \mathrm{L})$, systolic blood pressure $<100 \mathrm{mmHg}$ or diastolic blood pressure $<70$ $\mathrm{mmHg}$, and any histories of cancers, acute myocardial infarction, or congestive heart disease within the last 3 months were excluded from this study.

Blood were collected between 48 to 72 hours after stroke onset. Serum for S100B protein and GFAP measurement were kept at $-20^{\circ} \mathrm{C}$ until all samples were ready to be analyzed and the diagnosis of anterior circulation ischemic stroke was confirmed. $\mathrm{S} 100 \mathrm{~B}$ protein was measured with ELISA method using CanAg S100BB EIA from Fujirebio (Cat. 708-10) and the result was reported in ng/L. The concentration of GFAP was measured with ELISA method using Human GFAP ELISA reagent from R\&D (Cat. RD 192072200R) and the result was reported in $\mathrm{ng} / \mathrm{mL}$. The assays were performed at Research Department of Prodia Clinical Laboratory, Jakarta, Indonesia.

The severity of neurological deficit was measured with National Institute of Health Stroke Scale (NIHSS) score on their admission. The scores range from 0 as the minimal score to 42 as the maximal score. The NIHSS was classified as mild, moderate and severe if the score was less than 4,4 to 15 , and more than 15 , respectively.

The concentration cut-off of each biomarker was determined using receiver operating characteristic (ROC) curve and classified into 3 levels; high if the concentration was higher or equal to the high cut-off value, low if the concentration was lower than the low cut-off value, and intermediate if the concentration was between both of those cut-off values (Table 3 ).

Data was analyzed using SPSS 16.0 statistical analysis software for Windows (SPSS Inc., Chicago, IL, USA). The significant level of this analysis was set at $5 \%$. The distribution data was analysis with Kolmogorov Smirnov test. The concentration of the markers were compared among mild, moderate, and severe NIHSS groups with Kruskal-Wallis analysis. The correlation and the association between markers level and stroke severity was analysis using Spearman correlation test and chi-square test, respectively.

\section{RESULTS}

This study involved 143 subjects who had been diagnosed as anterior circulation ischemic stroke and fulfilled the criteria. Subjects consisted of male and female, aged from 30 to 85 years old with various associated disease as shown in table 1. Most of the subjects were admitted to hospital with moderate NIHSS $103(72.0 \%)$, and there were only $4(2.8 \%)$ subjects who came with severe NIHSS.

The result of the S100B protein and GFAP did not show a normal distribution data therefore the data was analyzed with nonparametric analysis.

Table 1. Baseline characteristic of the subjects $(n=143)$

\begin{tabular}{lc}
\hline Variables & $\mathrm{n}(\%)$ \\
\hline Age (years old) & $15(10.5)$ \\
$30-44$ & $93(65.0)$ \\
$45-64$ & $35(24.5)$ \\
$65-85$ & \\
Gender & $83(58)$ \\
Male & $60(42)$ \\
Female & \\
Admission NIHSS & $36(25.2)$ \\
Mild (score 0 - 3) & $103(72.0)$ \\
Moderate (score $4-15)$ & $4(2.8)$ \\
Severe (score 16 - 42) & \\
Associated disease & $32(22.4)$ \\
No/ Unknown & $5(3.50)$ \\
Cardiac disease & $82(57.3)$ \\
Hypertension & $7(4.9)$ \\
DM & $1(0.7)$ \\
Cardiac rhythm & $4(2.8)$ \\
Cardiac and hypertension & $11(7.7)$ \\
Hypertension and DM & $1(0.7)$ \\
Hypertension and fever &
\end{tabular}


The concentration of S100B protein $(p<0.001)$ and $(p=0.003)$ GFAP was significantly different among NIHSS groups on admission. Further post-hoc analysis using Mann Whitney test revealed a significant difference in $\mathrm{S} 100 \mathrm{~B}$ protein concentration among subjects with mild, moderate, and severe NIHSS. The more severe the NIHSS, the higher the S100B protein concentration. The median concentration of GFAP was significantly higher in severe NIHSS subjects than its concentration in mild and moderate NIHSS subjects. The median concentration of GFAP in the severe NIHSS subjects showed the highest level (Table 2, Figure 1).

The low and high cut-off values of S100B protein and GFAP were determined according to admission NIHSS (Table 3).
The cut-off values in table 3 were used to tabulate the subjects with high, intermediate, and low level of biomarkers in subjects with severe, moderate, and mild NIHSS (Table 4). There was a significant correlation between the $\mathrm{S} 100 \mathrm{~B}$ protein level and and the severity of NIHSS at admission $(r=0.351$; $\mathrm{p}<0.001$ ), but the GFAP did not show any significant correlation $(\mathrm{p}=0.432)$.

Subjects with moderate and severe NIHSS more frequently had an intermediate or high level of S100B protein than subjects with mild NIHSS (OR = 3.9; $\mathrm{p}=0.001)$. Subjects with severe NIHSS were more frequent to have a high level of $\mathrm{S} 100 \mathrm{~B}$ protein than the subjects with mild and moderate NIHSS (OR = 17.9; $\mathrm{p}=0.001)$ (Table 5).

Table 2. S100B protein and GFAP concentration according to the severity of NIHSS classification on admission

\begin{tabular}{lccc}
\hline \multirow{2}{*}{ Biomarker } & \multicolumn{3}{c}{ NIHSS classification on admission } \\
\cline { 2 - 4 } & Mild $(\mathrm{n}=36)$ & Moderate $(\mathrm{n}=103)$ & Severe $(\mathrm{n}=4)$ \\
\hline $\begin{array}{l}\text { S100B }(\mathrm{ng} / \mathrm{L}) \\
\text { Median }\end{array}$ & 63.31 & 88.93 & 511.55 \\
min-max $)$ & $(33.02-290.01)$ & $(26.79-2585.95)$ & $(224.58-1342.15)$ \\
$\begin{array}{l}\text { GFAP }(\mathrm{ng} / \mathrm{mL}) \\
\text { Median } \\
(\text { min-max })\end{array}$ & 0.047 & 0.043 & 0.374 \\
& $(0.012-0.109)$ & $(0.013-13.759)$ & $(0.051-25.501)$ \\
\hline
\end{tabular}

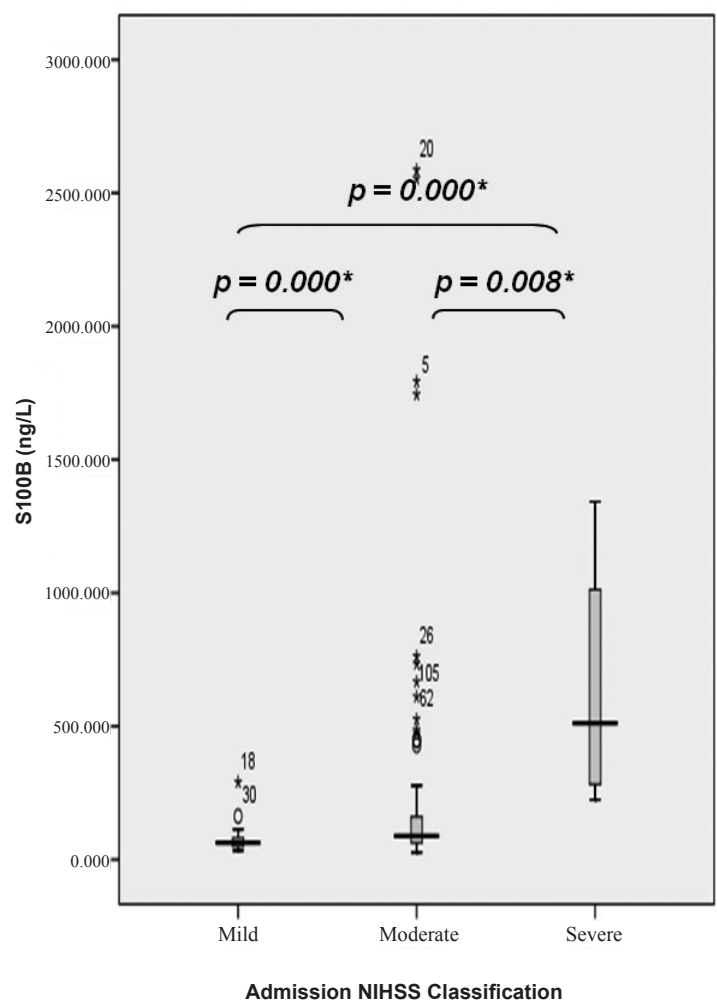

(a)

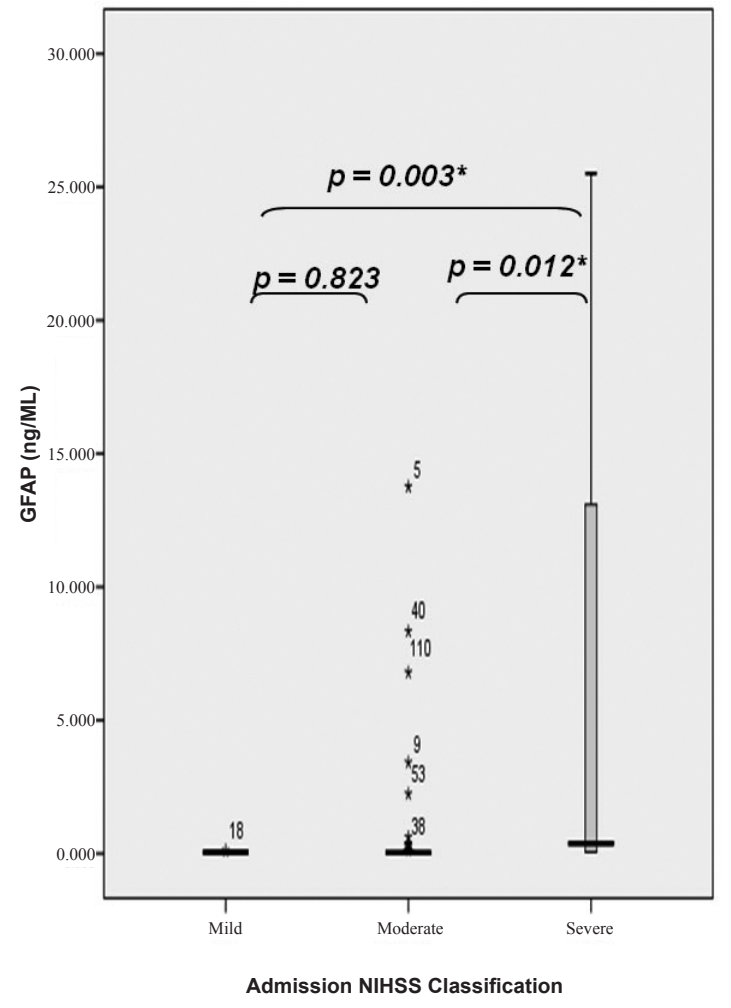

(b)

Figure 1. The difference of S100B protein and GFAP according to the severity of NIHSS on admission; (a) S100B protein (b) GFAP 
Table 3. The cut-off values of biomarker according to admission NIHSS

\begin{tabular}{lcccccc}
\hline Biomarker & Low cut-off & Sensitivity & Specificity & High cut-off & Sensitivity & Specificity \\
\hline S100B $(\mathrm{ng} / \mathrm{L})$ & 75.83 & 66.4 & 66.7 & 236.70 & 75.0 & 85.6 \\
GFAP $(\mathrm{ng} / \mathrm{mL})$ & 0.046 & 48.6 & 47.2 & 0.055 & 75.0 & 74.8 \\
\hline
\end{tabular}

Table 4. The cross tabulation and the correlation between biomarker levels and admission NIHSS

\begin{tabular}{lccccc}
\hline \multirow{2}{*}{ Biomarker } & \multicolumn{3}{c}{ Admission NIHSS $(\mathrm{N})$} & \multicolumn{2}{c}{ Correlation test } \\
\cline { 2 - 6 } & Severe & Moderate & Mild & $\mathrm{r}$ & $\mathrm{p}$ \\
\hline S100B & 3 & 19 & 1 & & \\
High $(\geq 236.70 \mathrm{ng} / \mathrm{L})$ & 1 & 48 & 11 & 0.351 & $0.001^{*}$ \\
Intermediate $(75.83-236.69 \mathrm{ng} / \mathrm{L})$ & 0 & 36 & 24 & & \\
Low $(<75.83 \mathrm{ng} / \mathrm{L})$ & & & & & \\
GFAP & 3 & 28 & 7 & & \\
High $(\geq 0.055 \mathrm{ng} / \mathrm{mL})$ & 1 & 20 & 12 & 0.066 & 0.432 \\
Intermediate $(0.046-0.054 \mathrm{ng} / \mathrm{mL})$ & 0 & 55 & 17 & & \\
Low $(<0.046 \mathrm{ng} / \mathrm{mL})$ & & & & & \\
\hline
\end{tabular}

*Spearman correlation test, $\mathrm{p}<0.05$

Table 5. The association of biomarker level and the severity of NIHSS on admission

\begin{tabular}{|c|c|c|c|c|c|c|c|}
\hline \multirow{2}{*}{$\begin{array}{l}\text { Intermediate and } \\
\text { high level of } \\
\text { biomarker }\end{array}$} & \multicolumn{3}{|c|}{$\begin{array}{l}\text { Moderate and severe } \\
\text { admission NIHSS }\end{array}$} & \multirow{2}{*}{$\begin{array}{l}\text { High level of } \\
\text { biomarker }\end{array}$} & \multicolumn{3}{|c|}{ Severe admission NIHSS } \\
\hline & OR & $95 \% \mathrm{CI}$ & $\mathrm{p}$ & & OR & $95 \% \mathrm{CI}$ & $\mathrm{p}$ \\
\hline S100B & 3.9 & $1.8-8.8$ & $0.001 *$ & S100B & 17.9 & $1.8-180.2$ & $0.001^{*}$ \\
\hline GFAP & 0.9 & $0.4-1.8$ & 0.703 & GFAP & 8.9 & $0.9-88.5$ & 0.057 \\
\hline
\end{tabular}

*Chi-square, $\mathrm{p}<0.05$

\section{DISCUSSION}

An obstruction of cerebral blood flow in ischemic stroke will reduce the energy that is required for normal metabolism of brain cells. The ischemic brain cells are unable to control the passage of ions through cell membranes and cause intracellular accumulation of calcium ion. ${ }^{3-5}$ Intracellular calcium accumulation will induce the apoptosis process and activate several enzymes that will result in the damage of the the brain cells. ${ }^{3,4}$

Although the disruption of blood brain barrier during ischemia allows the markers from the injured neuron or glial cells to be released into blood, ${ }^{6,7}$ the presence of the blood brain barrier hamper the early detection of the markers. ${ }^{8,9}$ The amount of the glial cells is 50 times greater than the amount of the neurons so that the measurement of glial markers was expected to give a higher result than the neuronal markers. ${ }^{10}$

Among several markers from glial cells that had been studied, S100B protein and GFAP were reported to have a significant association with stroke $(p<0.001) .{ }^{1,2}$
Higher concentration of S100B protein and GFAP had been associated with larger lesion and more severe clinical outcome. ${ }^{11-13}$

In this study, we evaluated S100B protein and GFAP in 143 patients diagnosed with anterior ischemic stroke. Most of subjects were admitted with moderate NIHSS (72.0\%) (Table 1$)$. We only got 4 subjects with severe NIHSS at admission, due to refusal in severe cases, or the stroke were not the first time, or the patients were admitted to the hospital more than 72 hours after the onset, or patients had already died within 48 hours after the onset.

The blood for S100B protein and GFAP analysis was collected between 48-72 hours after the stroke onset. This was performed as the result of some studies showed that the concentration of S100B protein and GFAP peak on day-2 and-3 after the stroke onset. ${ }^{11,13,14}$

The result of this study showed that there was a significant difference in S100B protein concentration among subjects who were admitted with mild, moderate, and severe NIHSS. The highest median concentration 
was found in subjects with severe NIHSS, a lower concentration was found in subjects with moderate NIHSS, and the lowest concentration was found in subjects with mild NIHSS (Table 2, Figure 1).

There was a different pattern of elevated S100B protein and GFAP concentration according to the severity of neurological deficit at admission. The S100B protein concentration showed a linear relation in conjunction with the severity of NIHSS. The more severe the NIHSS, the higher the median concentration of S100B protein. While, a significant elevated GFAP concentration was found only if the NIHSS had already been severe. A significant difference in GFAP concentration was found between subject with severe and non severe (mild-moderate) NIHSS (Table 2, Figure 1).

The different pattern of S100B protein and GFAP according to the severity of NIHSS might be due to the difference of molecular weight of these molecules. S100B protein $(10-12 \mathrm{kDa})$ that had a lower molecular weight will be easier to pass through the blood brain barrier than GFAP that had a greater molecular weight $(40-53 \mathrm{kDa}) .12,15,16$

In addition to molecular weight, a structural damage of cytoskeleton of astrocytes that were mainly composed of GFAP ${ }^{12}$ may indeed require a more severe damage than that was necessary to simply cause the leakage of S100B protein from the cytoplasm of astrocytes. One experimental study showed that the disintegration of astrocytes membranes which facilitated the escape of protein in the cytoplasms appeared after the cells were exposed to ischemia for more than 4 hours, ${ }^{17}$ while the expression of GFAP in astrocytes was depend on the severity of reactive astrogliosis. In healthy subjects, no GFAP was expressed. A varied GFAP expression began to appear in mild to moderate reactive astrogliosis, but a very high expression of GFAP was seen in severe reactive astrogliosis. ${ }^{18}$ GFAP was found more frequently in intracerebral bleeding $(82 \%)$ that had a rapid and more severe progression than the ischemic stroke (5\%) that had a slower process. ${ }^{19}$

Based on the cut-off values in table 3 , the concentration of S100B protein and GFAP concentration was classified as high, intermediate and low level. There was a significant correlation between the severity of NIHSS and the level of S100B protein $(r=0.351 ; p>0.001)$ (Table 4). Subjects with moderate and severe NIHSS at admission were frequent to have an intermediate or high S100B protein level than the subjects with mild NIHSS (OR $=3.9 ; 95 \%$ CI $1.8-8.8, \mathrm{p}=0.001)$. Subjects with severe NIHSS were also more frequent to have a high S100B level than the mild and moderate NIHSS (Table 5). On the contrary, GFAP level did not show any significant correlation with the severity of NIHSS (Table 4). This might be due to the limited number of subjects with severe NIHSS in this study. Further study with a greater number of subjects with severe NIHSS was necessary so that GFAP measurement might be used as a significant marker for severe condition.

In conclusion, the concentration of S100B protein and GFAP showed a different pattern in ischemic stroke. This study showed a weak significant correlation between S100B protein and the severity of NIHSS. The more severe the admission NIHSS, the higher the S100B protein concentration, while the GFAP concentration was significantly higher if the NIHSS had been already severe.

\section{Acknowledgments}

We thank Prodia Education and Research Institute for funding this research.

\section{REFERENCES}

1. Lynch JR, Blessing R, White WD, Grocott HP, Newman MF, Laskowitz DT. Novel diagnostic test for acute stroke. Stroke. 2004;35(1):57-63.

2. Whiteley W, Tseng MC, Sandercock P. Blood biomarker in the diagnosis of ischemic troke: A systematic review. Stroke. 2008;39:2902-9.

3. Endres M, Dirnagil U, Moskowitz MA. The ischemic cascade and mediators of ischemic injury. 2009. In: Fisher M, editor. Handbook of clinical neurology, vol 92 ( $3^{\text {rd }}$ series) Stroke. Part I. Boston: Elsevier; 2009. p. 31-41.

4. Graham SH, Hickey RW. Molecular pathophysiology of stroke. In: Davis KL, Charney D, Coyle JT, Nemeroff C, editors. Neuropsychopharmacology: the fifth generation of progress. Pennsylvania: American College of Neuropsychopharmacology. 2002. p. 1317-26.

5. Lakhan EL, Kirchgessner A, Hofer M. Inflammatory mechanisms in ischemic stroke: theraupetic approaches. J Transl Med. 2009;7:97-107.

6. Saenger AK, Christenson RH. Stroke biomarkers: progress and challenges for diagnosis, prognosis, differentiation, and treatment. Clin Chem. 2010;56(1):21-33.

7. Hill MD. Diagnostic biomarkers for stroke: a stroke neurologist's perspective. Clin Chem. 2005;51(11):2001-2.

8. Jauch ECJ. Biomarker advances in acute ischemic stroke. In: Advancing the Standard of Care: Cardiovascular and Neurovascular Emergencies. Division of Emergency Medicine, Washington University School of Medicine, Cincinnati; 2005

9. Jickling G, Xu H, Sharp F. Biomarkers of ischemic stroke. US Neurology. 2009;5:52-4.

10. Liswaty E, Wijaya A, Ranakusuma TAS. Biochemical markers for differential diagnosis of stroke: a biochemical marker study of S100B protein, neuron specific enolase (NSE), myelin basic protein (MBP), and heart-type fatty 
acid binding protein (H-FABP). Indonesian Biomedical Journal. 2009;1:68-72.

11. Buttner T, Weyers S, Postert T, Sprengelmeyer R, Kuhn W. S-100 protein: serum marker of focal brain damage after ischemic territorial MCA infarction. Stroke. 1997;28(10):1961-5.

12. Missler U, Wiesmann M, Wittmann G, Magerkurth $\mathrm{O}$, Hagenstrom H. Measurement of glial fibrillary acidic protein in human blood: analytical method and preliminary clinical results. Clin Chem. 1999;45(1):138-41.

13. Wunderlich, MT, Ebert AD, Kratz T, Goertler M, Jost S, Herrmann M. Early neurobehavioral outcome after stroke is related to release of neurobiochemical markers of brain damage. Stroke. 1999;30(6):1190-5.

14. Herrmann M, Vos P, Wunderlich MT, de Bruijn CHMM, Lamers KJB. Release of glial tissue-specific proteins after acute stroke: a comparative analysis of serum concentration of protein S-100B and glial fibrillary acidic protein. Stroke. 2000;31(11):2670-7.

15. Ali MS, Harmer M, Vaughan R. Serum S100 protein as a marker of cerebral damage during cardiac surgery. Br J Anaesth. 2000;85(2):287-98.

16. Michetti F, Gazzolo D. S100B Protein in biological fluids: a tool for perinatal medicine. Clin Chem. 2002;48(12):2097-104

17. Yu ACH, Wong HK, Yung HW, Lau LT. Ischemia induced apoptosis in primary cultures of astrocytes. Glia. 2001;35(2):121-30.

18. Sofroniew MV, Vinters HV. Astrocytes: Biology and pathology. Acta Neuropathol. 2010;119(1):7-35.

19. Foerch C, Curdt I, Yan B, et al. Serum glial fibrillary acidic protein as a biomarker for intracerebral haemorrhage in patients with acute stroke. J. Neurol. Neurosurg. Psychiatry. 2006;77(2):181-4. 